University of Rhode Island

DigitalCommons@URI

Open Access Master's Theses

1978

\title{
Study on Birth Order and Affilitation in Social-Help Organizations
}

Ruth G. Radin

University of Rhode Island

Follow this and additional works at: https://digitalcommons.uri.edu/theses

\section{Recommended Citation}

Radin, Ruth G., "Study on Birth Order and Affilitation in Social-Help Organizations" (1978). Open Access Master's Theses. Paper 1712.

https://digitalcommons.uri.edu/theses/1712

This Thesis is brought to you for free and open access by DigitalCommons@URI. It has been accepted for inclusion in Open Access Master's Theses by an authorized administrator of DigitalCommons@URI. For more information, please contact digitalcommons-group@uri.edu. 
STUDY ON BTRIY ORDER

AND AFFILITATION

IN SOCIAL-HELP ORGANIZATIONS

\author{
BY i \\ RUTH G. RADIN
}

A THESIS SUBMITTED IN PARTIAI FULFILLMENT OF THE REOUIREMENTS FOR THE DEGREE OF MASTER OF SCIENCE

IN

CHILD DEVELOPMENT AND FAMTII RELATIONS

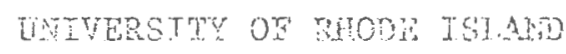
1978 


\section{THESIS ABSTRACT}

This study researched the relationship between birth order and affiliation in three social-help organizations and represents a replication and extension of a study done by Dr. Stephen Misovich ${ }^{1}$ in 1973. The three social-help organizations included Lean Iine, an organization to help members to reduce weight; Alcoholics Anonymous, an organization to help members stop drinking; and 5-Day-Plan-ToQuit-Smokjng, an organization to help members stop smoking.

X Birth order is defined as the ordinal position of an individual among his or her siblings. "Only" children were defined as first borrs. The size of a family was the total number of sibiings in the family.

It was hypothesized that there would be a significant difference between the expected number of first borns and the observed number of first borns in each social-halp organization, …… significantly more cbserved first borns than expected first borns.

Birth orcer iuformacion was obtained from one hundred merbers ci. Len Iine, fifty-two members of Alcoholics Anomyoue, and thinty-six metabers of 5-Tay-Plan-To-Quit-Snoking. The same bith oxder questionnaire was admintered in the same manner to each of the groups with changes in voding suiting each organization.

\footnotetext{
${ }^{1}$ stephen Misovich, "Birth order, offiliation, and meinership
} in Weight Wachers," Psychologteal Feports, 1973, 32, 94. 
Subjects came from varied social and economic backgrounds. Geographically, subjects were in attendance at meetings in the New London, Connecticut generai vicinity.

Both males and females were subjects in the study. The mean age for Lean Line, Alcoholics Anonymous and 5-Day-Plan-To-QuitSinoking was 41.2 years, 42.3 years, and 39.8 years, respectively.

The lengths of time members enrolled in Lean Line varied from one day to thirty-two weeks. Alcoholics Anonymous subjects were members from a range of one day to thirty years. Snokers were members for only five days as that was the length of the withdrawal clinic.

The data from the questionnaire was compiled and results tabulated. Significantly more first borns were observed in the Lean Line group. $\left(x^{2}=3.62\right.$, df $\left.=1, p<0.6\right)$. Significantly more first borns were observed in the Alcoholics Anonymous group. $\left(x^{2}=8.11\right.$, df $\left.=1, p<.005\right)$. I.ess than the expected number of first borns were observed in the 5-Day-Plan-To-Quit-Smoking group. Thus, two of the three hypothese.s wers verified.

Thje study adds further support to prior studies that indicate a definite relationship between birth order and affiliation as defined by a dasire to belong to certain groups. 


\section{ACKNOWLEDGMENTS}

I wish to thank my husband, Larry Radin, who has provided encouragement, love, assistance, and statistical expertise. I wish to thank Dr. Helen Greene, my advisor, who has been helpful and highly supportive throughout my master's studies.

I would also like to thank my other comnittee members, Dr. Francis Russo, and Dr. George Fitzelle, for their advice.

I am grateful to Dr. Stephen Misovich of Providence College for giving me permission to replicate his study. His advice and interest were extremely valuable.

I would also like to thank Diane Rubin for helping me arrange to collect data frum Lean Line. All the Lean Line lecturers and members have been very accommodating. I would also like to thank members of Alcoholics Anonymous and 5-Day-P1an-To-Quit-Smoking for sharing their time and information.

Lastly, I would like to thank my parents who were supportive. in innumerable ways. 
$\underline{T} \underline{A} \underline{B} \underline{E} \underline{\mathrm{O}} \underline{\mathrm{E}} \underline{\mathrm{C}} \underline{\mathrm{O}} \underline{\underline{Y}} \underline{\underline{\mathrm{I}}} \underline{\mathrm{E}} \underline{\mathrm{T}} \underline{\mathrm{S}}$

Chapter

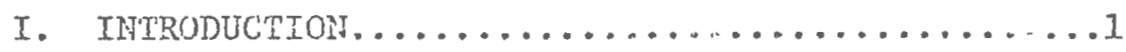

II. REVIEV OF LITERATURE................

III. TROCEDURE......................

IV. RESULTS..........................

W. DISCUSSION \& INPIICATIONS FOR FUTURE RESRARCI.. 30

APYENTIX A: QUESTTONNAIRES \& DUAGRAMS................

APFPADTX B: GRAPHS........................

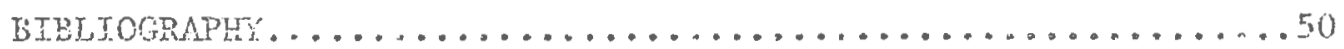




\section{INTRODUCTION}

Birth order, the ordinal position of a sibling within a family, and its relationship to personal characteristics has been the subject of extensive, but conflicting research since the pioneering studies of. Schacter. $^{1}$ Two lines of investigation have emerged. Early studies attempted to indicate that personality traits are related to specific ordinal positions. More recent works have centered on the connection between birth order and behavior patterns.

One area in the behavioral field which has received attention is the relationship between birth order and affiliation. Several studies have shown that first born or only children have stronger affjliative tendencies than later born children; i. e.., to yield to group pressure to conform. One such study was done by Stephen Misovich ${ }^{2}$ and serves as the basis of tiris writer's investigation into birth order.

This writer's study will replicate and extend Misovich's research, "Birth order, affiliation, and menbership in Weight Watchers," Misovich hypothesized that first borns would demonstrate a preference

$1_{\text {Stanley Schacter, The Psychology of Affiliation, Stanford }}$ Ginversity Press, Stanford, Cai., 1959.

${ }^{2}$ stephen ilisovich, "Birth order, affiliation, and membersinip in Weight Watchers," Psychological Reports, 1973, 32, 94. 
for social, as opposed to individual, methods of coping with anxietyassociated eating behavior. To test his hypothesis, Misovich designed a questionnaire to obtain birth order information, age, number of siblings, length of merubership, and weight 1oss. Information was obtained from twenty-nine female members of a Weight Watchers class. The class mean family size (3.3) yielded an expected frequency of eight first borns and twenty-one later born members. The obtained frequency of fourteen first borns and fiften later born mambers differed significantly from the expected ralues lending support to the hypothesis. No significant differences were found in regard to age, length of membership and weight loss between first born and later born members. Misovich suggests that his findings must be interpreted with caution since most of the members had only recently enrolled in the prograrn and were members for less than six months.

In order to replicate this study, this writer received permission from Misovich. Based on his recommendation, the data collection was enlarged to include other social-help organizations to determine if the phenomenor generally holds true.

Therefore, this writer's study will examine first borns (vs. later boris) and indicate whether they not only denonstrate a preference for social methods (as opposed to individual methods) of coping with weight loss, but also examine if this is valid in other organizations that help findividuals to stop snoking, and to stop consuming alcohol. 
Three hypotheses emerge:

1. There will be a significant difference between the expected number of first borns in a Lean Line group (a weightreduction organization) and the observed number of first borns in this group.

2. There will be a significant difference between the expected number of first borns in an Alcoholics Anonymous group

(a drinking withdrawal organization) and the observed number of first borns in this group.

3. There will be a significant difference between the expected number of first borns in a 5-Day-Plan-To-Quit-Sinoking (a smo'ring withdrawal group) and the observed number of first borns in this group.

As Misovich's hypothesis proved true, and this is a replication of his study, it would follow that these hypotheses, particularly the first one, will be verified. 


\section{REVIEW OF ISITERATURE}

No review of birth order-affiliation literature would be complete without an examination of Schacter's studies. ${ }^{1}$ Subjects for his study were female students enrolled in Introductory Psychology at the University of Minnesota. Two experimental conditions were created, one of high anxiety and one of low anxiety. In the high anxiety condition, girls entered a room filled with an array of electrical equipment and were told that they were to receive electrical shocks as part of the experinent. "These shocks will hurt, they will be painful," the girls were told.

In the low anxiety condition, girls again entered a rom with the identical conditions. However, this time the experinenter told the group, "I assure you that what you will feel will not in any way be painful."

From this pcint on, experinental proceciures were the same. The experinanter told the group that there would be a slight delay and, subjects were given to opporicunity to wait together or alone. Via quesionaires filled out by the subjects, information was then collected.

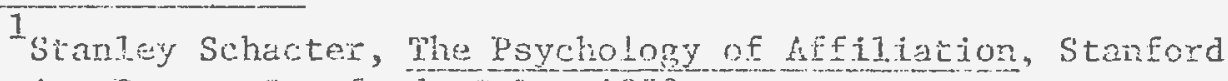
Jotoersity Press, Stanford, Cal., 1959. 
The results provide some insight into affiliative behaviors. In the high anxiety condition, 18.8 percent of the subjects refused to continue: 0 percent in the low anxiety condition refused to continue. In the high anxiety condition, 63 percent of the subjects chose to remain "together" while only 33 percent chose to be "together" in the low anxiety situation. Thus, Schacter indicated that anxiety leads to the arousal of affiliative tendencies.

Schacter hypothesized that first born and only children would manifest stronger affiliative needs than later born children. Pooled results from his experiments showed that thirty-two of the first born subjects in the high anxiety situation chose to be together compared to twenty-one later born subjerts. In the low anxiety condition, fourteen of the first born subjects chose to be together compared to twenty-three later born subjects.

On Schactex's born scales of anxiety, first borns and only borns indicated that they were considerably more nexvous than later borns. On the measure of willingness to go through with the experiment, 28 percent of all first borns and only born subjects were unilling to continue and only 8 percent of all later borns refused to continue the experiment.

Schacter attempted to apply his findings that anxious first bons tend to affiliate to psychotrecapy, fighterpilot effectiveness, dependency, alcohoiism, and hunger. 
As Schacter's studies have served as a landmark in birth order research, it follows that other researchers would attempt to replicate and possibly disprove his theories. In fact, a major part of the birthorder affiliation research stems from Schacter's work. However, studies attempting to replicate and extend Schacter's findings have reported conflicting evidence.

In 1962, Weller ${ }^{2}$ did an exact replication of Schacter's study using students at the University of Connecticut. Students were presented with the same apparatus and high and low anxiety conditions were presented. No significant birth order differences were revealed that would contradict. Schacter's research. Weller suggests that there were some socio-economic variations in his group compared to Schacter's group. Weller suggests that results are in accordance with the findings in birth order literature. They are, "...for the most part, contradictory and inconclusive." Sarnoff and Zimbardo ${ }^{3}$ attempted to replicate Schacter's research on affiliation arousal. However, their focus was to differentiate betwesn fear and arxiety. Seventy-two subjects were randomly assigned to four. experimental treatments in which high and low levels of fear and anxiety were manipulated. The results showed that while the desire to affiliate as fear increases (in accordance with Schacter's findings), the opposite is true of anxiety; as anxiety increases, the desire to affilinte decreases. Thus, Sarnoff and Zimbardo indicated a distinction betwean fear and anxiaty.

2Leonard Weller, "The rejationship of hirth order to anxiety: A replication of the Schacter findings," Sociometry, 1962, 25 (4) 415-417.

3. Sarnoff and P. Zimbardo, "Anxiety, fear and social arfiliation," Journal of Abrotmal and Social Psychology, 196i, ó2, 355--359. 
Joseph Masling 4 used three samples of students to test Schacter's work on birth order and the need for affiliation. Masling hypothesized that for ireshmen students about to enter college, the thought of dormitory life and leaving hone imposes anxiety. Therefore, first born and only born children should choose to room with arother student to alleviate this anxiety. Questionnaires completed by students showing their preferences for single or double rooming situations were examined to obtain the necessary statistics. No relationship was found between first and later borns and a preference from rooming alone or with others.

Smart's $s^{5}$ study was also based on the findings of Schacter's research. Birth order and social group information was collected from 370 uriversity students. The results of the data iend support to Schacter's affiliative behavior theory. First born males more often then later born males are social group members. But, there were no birth order differences for females. Thus, Smart assunes tilat first born males have greater affiliative neers than later born males.

Other studies on affiliation use Schacter's findings as a basis for their cesearch but do not attempt to replicate Schacter's wosk. For example, Strumpfer ${ }^{6}$ collected data via a questionnaire

"Joseph Masiling, "Birth order and need for affilidtion," Peychological Reports, 1965, 16 (2) 631-632.

5 Reginald Smart, "Social-group membership, 1sadership and birth order," The Journal of Sacirl Psychology, 1965, 67, 221-225.

6. J. W. Strumper, "Fear and affiliation during disaster," Journal of Social Psychology, 1970, 82 (2) $263-263$. 
from 161 adults after a flocd. lie found sigilticant positive interrelationships between fear and affiliative tendencies. First borns reported higher fear than did later borns. Affiliation also showed this association.

In another disaster situation, Zucker, Manosevitz, and Ianyon ${ }^{7}$ collected data through questionnaires. Following the 1965 power failure in New York City, information was collected from 100 adults, It was hypothesized that first borns would be more anxious and more affiliative than later borns stranded in this situation. While the results supported the anxiety hypothesis, the affiliation hypothesis received only some confirmation. Fifty-three percents of the first born wonen expressed a strong preference for affiliation. Cniy 21 percent of the first born mea expressed this preference. While tany studies have shown a relationship between aruiety and effiliation, and affiliation and birth order, little research has correlated the variables of anxiety and birth order. In an Indian secondary school, students ware tested on the Taylor's Manifest Anxiety Scale. Reeearehers George and Devadas ${ }^{8}$ fount that first born students had a significantly higher level of anxiecy than did other ordinal positions.

7 Robert zucker et al., "Birth order, anxiety, and affiliation during a crisis," Tournal of Persondity and Soctal Psychology, $1363,3,354-359$.

${ }^{3} E$. I. George and R. Devadas, "Marifest anzisty as a function of birth order," Joumal of Indier Acedeny of Applied Psychology, $197 \%, 8,39-40$. 
Examination of the affiliative tendencies of firșt borns can be applied to membership in organizations such as fraternities and sororities. Baker and $0^{\prime}$ Brien $^{9}$ did such a study at Lehigh University. Data was collected concerning ordinal position fxom 90 percent of an entire freshmen class in 1963. Contrary to prior literature on affiliation, significantly more later born students affiliated with a fraternjty than did first borns. Baker and O'Brien speculated about the cause of this by considering the elements of familial relationships rather than the first born's jealous protection of the exclusive relationship he has had with his parents (as is speculated in the majority of the literature). According to these researchers, a fraternity provides certain surrogate parental figures. Moreover, a newly-joined fraternity "brother" would be treated as a "little brother". Thus, first borns may be reluctant to join fraternities and enter into a subordinate position.

Forbas ${ }^{10}$ did further studies extending the work of Schacter and Baker and O'Brien. Baker and O'Brisn's findings were inconsistent and contrary to Schacter's findings. Forbes' attempt at replication was done at Millikin University, a coeducational college. Lata was obtained from 328 males. The percentages of only born, first born, middle born and lasc born males who were members of a fraternity indicated that there was no association between birth ordex and fraternity affiliation.

\footnotetext{
9". Baker and G. O'Brien. "Birth order and Fraternity affiziation," Journal of Social Psychology, 1969, 78, 41-43.
}

${ }^{10}$ G. B. Forbes, "Fraternity or sorority membership and birth order: Sex differcnces and problems of reliability," Journal of Social Psycloology, 1970, 82 (2) 227-228. 
The percentages of only born, first born, middle born, and last born females who were members of a sorority indicated proportionally more only born and first born females, were members of sororities. This is consistent with Schacter's findings.

During the following year, 1969, a second sample of 113 males was obtained. Again, birth order information was obtained. The results indicated proportionally more first borns and last borns were members of fraternities.

On the University of Rhode Island campus a study was done to see if there was a predominance of first borns signing up for sororities. 11 Freshman women who had indicated a desire to pledge a sorority were asked to complete a birth order questionnaire. A follow-up compared birth order of those who had signed up for sorority rush with those women that had received bids to join a. sorority. Results indicated that a significantly higher number of first borns anticipated sorority acceptance.

British researchers Murdoch and Stith ${ }^{12}$ discovered in their affiliation studies that first born maies are more frequently fraternity merbers; prefer company when shopping, and tend to marry earljex. First born females belong to more oxgantiatons o wtain dates more easily, and make friends more easily.

17 Carole cumps, "An investigation of ordinat position and sorority affiliation at U.R.I.," Unpublished Stidy, 1971.

${ }^{12} \mathrm{P}$. Muràoch and G. Sinith, "Birth order and arficliatior," British Jocrnal of Social and Clinical Psychology, 1969, \& (3) 235-245. 
While infinite studies on fraternity and sorouity-membership could be conducted, the results will always vaxy due to socio-economic differences, geographical differences, and the importance and influence of such organizations on a particular campus.

Affiliation tendencies of first borns can also be indicated through other methods. Dember ${ }^{13}$ administered the Thentatic Aptitude Test (TAT) to forty-four students and scored the results for need-affiliation (nAff). Based on previous research, it was hypothesized that first borns had a significantly and markedly higher svarage nAff than did later borns, which lent support to the hypothesiz.

Connors ${ }^{14}$ hypothesized that the only child, first born, and later born child receive progressively less attention from parenis as a result of the birth of new siblings. This, Connors predictei, would lead to an increase in needs for affiliation and a lower expactation of affection from others. TAT and Schutz's FIRO (Fundamental

Interpersonal Relations Orientation) tests were given to 157 fraternity students. As hypothesized, students tended to have lover scores the higher their birtin order. This indicated less expectancy of affiliative reward.

Many theories about the cause of the relationship between first borns and affiliation have been developed. Hamilton's 15 study is based on the assumption that "the drive for self-evaluation" is ai important

13 W. N. Denber, "Bixth order and need arfiliation," Journal of Personality, 1963, 31 (3) 837-852.

${ }^{14}$ Keith Conoors, "Birth ordar and needs for affiliation" Journal of Personality, 1553,31 (3) $837-852$.

15 M. I. Hamilton, "Affjliativa behaviors as fi function of approach arid avoidance affiliation motivas, opinion, evaluation and birth order," Jocrial of sociat Psychotogy, $1967,72,61-70$. 
factor in the need for affiliation. He hypothesized that oldest or only children have stronger affiliative tendencies than do later born children. Under his experimental conditions, these early borns would exhibit a high drive for evaluation. One hundred and ninetytwo subjects were assigned to two experimental conditions aimed at creating different levels of drive for self-evaluation. Subject differences in affiliation motivation, ordinal position and sex were analyzed. However, no significant differences occurred between the two experimental conditions. Regional and sociological differences were suggested as possible causes.

Zimbardo and Formica ${ }^{16}$ evaluated the validity of self-esteem as a variable mediating the relationship between ordinal position and affiliation. They speculated that first borns have lower self-esteem than do later borns. Thus, they tend to affiliate when their selfesteem is questioned. The first born child's desire to affiliate was moxe intense under conditions of fear arousal or stricter parental. control.

Research correlating birth order with membership in any of the faniliar social-help organizations, specifically veight raduction, smoking, and alcohol withdrawal, was found to be extremely limited. In addition to the Misovich ${ }^{17}$ study, Schacter ${ }^{18}$ attempted to make an

16.9 . Zimbardo and R. Formica, "Emotional comparison and selfesteem as determinants of affiliation," Joumal of Personality, 1963, 31, 141 - 162.

17 Misovich, op. sit.

${ }^{18}$ Schacter, 요. 도t․ $62-63$. 
analogy based on his demonstrated experimental relationships. He speculated that later borns will be overrepresented among chronic alcoholics and early borns underrepresented. He refers to alcoholism as representing an asocial means of coping with disturbance. Thus, first borns would be less prone to turn to this socially unacceptable method of coping. Smart ${ }^{19}$ provided information contrary to schacter. Schacter found that his subjects all wished, under anxiety situations, to affiliate with persons in the same anxiety situation. It would be expected, therefore, that first born and only child alcoholics would more often become involved in Alcoholics Anonymous, as this therapy constitutes an ideal opportunity to affiliate with persons in the same situations.

Smart's findings indicated that first born and only born children do not becone involved in psychotherapy move frequently than do later borns. An explanation for this discrepancy, according to Smart, may be connected to the alcoholic populations studied. Earlier authors present little descriptive data about their populations.

Delsint $^{20}$ hypothesized that the overrepresentation of youngest children among alcoholics was due to the presence of only one parent in families of last born chilaren. He exanined records of 275 women in Toronto and discovered that last borns were greatly overrepresented among those raised since the age of five by only one parcnt.

${ }^{19}$ R. Smart, "Alcoholism, birth order, and fanily size," Iournal of Abnormal and Social Psychology, 1963, 66, 17-23.

${ }^{20} \mathrm{~J}$. E. E. Delint, "Alcoholism, birth order and socializing agents," Journal of Personality, 1963, 31, :08-16. 
Blane and Barry ${ }^{21}$ examined the relationship between birth order and alcoholism and found that birth order as an independent factor camnot be a causative factor in alcoholism. However, individuals in certain birth positions may be more likely to develop alcoholism.

In a study of Japanese male alcoholics, Kosugi and Tanaka ${ }^{22}$ found the incidence of alcoholism was significantly higher in first borns. This was contrary to what previous studies had indicated. As Kosugi's focus was on parental deprivation in regard to alcoholism, it was found that more last borns from deprived homes tended to become alcoholics.

As the literature on weight reduction and alcoholism in regard to birth order is sparse, so is the literature correlating smoking and birth order. Many of the traits which distinguish smokers and non-smokers are the types of traits commonly thought to be learned in childhood. Therefore, long-term studies must be conducted to obtain information. It is speculated that adult smoking patterns could be predicted from objective measures obtained in childhood. 23 Based on these theories, Forbes ${ }^{24}$. hypothesized that if this is true, that a significant relationship should be found between birth order and smoking behavior. Stnoking behavior data was obtained

${ }^{21}$ H. T. Blane and H. Barry, "Birth order and alcoholism: A review," Quarterly Journal of Studies on Alcohol, 1973, 34 (3) 837-852.

${ }^{22} \mathrm{Y}$. Yosugi and M. Tanaka, "Parental deprivation, birth order and alcoholism," Japanese Journal of Studies on Alcohol, 10 (3) $70-77,1975$.

23 $\mathrm{W}$. E. Simon, "Ordinal position of birth in the family constellation and adult smoking behavior," Iournal of Social Psychology, 1973,90 (1.) $277-273$.

${ }^{24}$ G. B. Forbes, "Siroking behavior and birth order," Psychological Reports, 1970,26 (3) 157-158. 
from 804 college studenis. Subjects were divided into four groups: only borns, first borns, middle borns, and last borns. The percentages of smokers follows respectively: $19,25,31,35$. Anaiysis of the data suggests that increases in birth ranks are associated with increases in the frequency of smoking.

It is obvious that the entire topic of birth ordex is still a mystery to researchers. Studies followed by replications zarely confirm origiral findings. The information researchers have obtained is conflicting and inconsistent. 


\section{III \\ PROCEDURE \\ Sample}

Subjects for this study were selected from three organizations: Lean Line, Alcoholics Anonymous, and 5-Day-Plan-To-Quit-Smoking. Subjects were selected from those members who attended meetings of these organizations in the New London, Connecticut area.

Members came from varied backgrounds economically and socially. Subjects remained totally anonymous and were assigned a numeral on their questionnaire for recording purposes.

While no attempt was made to monitor the sex of the subjects, a high percentage of Lean Liners were female (96\%). The other two organizations yielded expected percentages of males and females.

\section{Organizations}

Lean Line promotes membership by appealing to the public with newspaper advertisements that stress the "psychological. approach to losing weight with an exclusive university-tested Behavior Modification Technique." (See Appendix A). The major thrust of the Jean Line program is the belief that the human make-up is both chenical and emotional. As a result, the dieter must accept the fact tl.at familiar foods that give pleasure and comfort are an essential part of a successful diet. By use of a well balanced diet supplenented by these familiar fcods, the dieter becones acclimated toward better eating habits and weight loss.

The program is composed of three stages: Basic Diet, Cruise Diet and Permanent Maintenance Diet. The program begins wi.th the Basic Diet for losing weight. It encompasses a wide variaty of foods that 
the dieter can eat as well as a select group of the familiar foods described above known as "soul foods". No calorie counting is done. Meals are portioned by weight rather than by size or calorie count. Certain foods are required to be eaten daily to maintain a balanced diet such as fruits, milk and bread as well as a protein portion at each mealtime. A booklet "Passport to Lean Line", is distributed to each menber for reference at home.

The format of the Cruise Diet stipulates that the dieter stop dieting for one week at every ten-pound weight loss interval. This is to acquaint the dieter with the reality-of weight loss. It is felt, according to Lean Line, that ten-poind intervals are Eairly easily attainable and provide a realistic goal. It is the belief of the Lean Line program that human beings need rewards to continue dieting. This is the Lean Line theory of behavior modification. The dieter is rewarded for modifying eating habits by going on the Cruise Diet.

The Maintenance Diet is selected after weight. loss to help the dieter to maintain his goal. The Haintenance Diet provides the dieter with a diversified menu to keep reight at an even level.

Once a dieter has reached a goal set by Jean Line (determined by height and body build), membership is free of charge providing Inembers weigh-in every month and do not gain more than two pounds abrve thetr goal. 
Reinforcements are provided in a variety of ways in addition to the Cruise Diet and Maintenance Diet. Weight losses are announced at each meeting to the group. Also, Lean Line pins are awarded at the first ten-pound weight loss and at goal.

Lean Line group leaders (lecturers) have been through the program and are trained to offer understanding and encouragement to those involved in the mutual problem of weight reduction.

Lean Line has been operating in the area for approximately six months. Group size varied from five to thirty members attending at a class.

The psychology of Lean Line stresses, "You (the dieter) wil1 probably fail on your diet or in attempting to maintain your weight 10 ss at one time or another." 25 The program stresses that reactions to food are the result of conditioring. Patterns of eating were established early in life before the dieter had any control. It is vital to accept temporary failure without guilt. Self-approval is of vital importance.

Alcoholics Anonymous is an organization for alcoholics of all ages. It is a non-profjt organization without any dues or charges. It is not allied with any organization or sect, although meetings are generally held in religious buildings. According to the Alcoholis Anonymous handbook, A.A. members believe in God or a power higher than themselves.

${ }^{25}$ Antonia Marotta and Lorraje Wurtzel, Diet Cybernecies for Lean Lines, Pyranid Books, New York 1974. 
The major purpose of this organization is to help members to abstain from alcohol and to help other alcoholics achieve sobriety.

Meetings are headed by reformed alcoholics who begin each meeting with a statement that is universal to a1. Alcoholics Anonymous meetings nationwide and summarizes the major beliefs of this organization,
"My name is and $I$ am an alcoholic. Alcoholics Anonymous is a fellowship of men and women who share tiieir experience, strength ard hope with each other that they may solve their common problem and help others to recover from al.coholism. The only requirement for member- ship is a desire to stop drinking. There are no dues or fees for A.A. nembership; we are self- supporting through our own contributions. A.A. is not allied with any sect, denomination, politics, organization or institution; does not wish to engage in any controversy; nejtier endorses nor opposes and causes. Oxr primary purpose is to stay sober and heip other alcoholics to achieve sobriety."

The sincerity and deep comnitiment that menbership in Alcoholics Anonymous provides is reflected in the A.A. Serenity Prayer, "sod grant me the serenity to accept the things I cannot change, courage to change the things I can, and wisdon to know the disference."

By sharing the mutial problem of alcoholian, Alcoholics Anonymous memters can receive the ancouragement of the group. Members are open about tieir experiences publicly, but they respect anonymity at metings. 
It is the theory of Alcoholics Amonymous members that an alcoholic should not attempt to tackle all the problems that have occurred due to drinking at once. Rather, each problem and each day should be handled separately. Experiences and problems that are drinking related are vast. Alcoholics must not only deal with personal problems but also those relating to family, job, and society. This awesome task needs the support and affiliation of a group such as Alcoholics Anonymous.

5-Day-Plan-To-Quit-Snoking is an organization whose sole purpose is exactly what the title describss. 5-Day-Flan-To-Quit-Smoking sessions are conducted worldwice for comunities by local Severth Jay Adventist churches. These clinics have been conducted periodically for fifteen years. They are held through the cooperation of the American Cancer Society, the Anerican Heart Association, and cha American Lung Association. A fee of $\$ 3.00$ is chargied per clinic lasting five days.

Set meeting plans are designed for each of the five days. Meetings feature filns on the effects of smoking. On several of the sessions doctors trained in the hazards of snoking, such as laryngectomists, describe the effects of ewoking on the body.

The najor emphais of these neotings is upon the member:" desire to stop snoking. Members are frequently called upon to repeat alouj, "I enoose not to sacko." 
To enable members to overcome initial problems of smoking withdrawal, many hints are given out to alter behavior and eating patterns that affect smoking. 5-Day-Plan-To-Quit-Smoking recognizes the difficulties in smoking withdrawal, and members team up with "buddies" who they call upon during difficult times.

The nightly group meetings sérve as a support as each member shares a mutual desire. Meetings are headed by the pastor of the church. A limited number of sessions are held annual.ly.

\section{Instruments}

Data was obtained through voluntary anonymous questionnaires. The content of the questionnaires is based on Misovich model. (See Appendix A). Some changes are based on his recommendation. A double check question was added to ensure obtaining correct birth order information.

\section{Collection of Data}

The meetings attended were selected purely by random and varied in time, day and location. Information was collected over a period of three inonths (October - December 1977).

As any meraber attending a meeting was free to voluntarily participate in the survey, a wide age range was obtained from 11 years to 70 years old.

This witer collected all the data herself, and introduced herseif in the same manner at every meating. The same designated questionnaire was used for each organization for each subject. Questionaires were administered to the group. 
Two cf these organizations, Lean Line and 5-Day-Plan-ToQuit-Smoking, advertise through local newspapers. Alcoholics Anonymous is listed in the telephone directory and is advertised mostly through religious organizations and word-of-mouth.

\section{Analysis of Data}

Data that was obtained was recorded on charts and examined. Based on the class mean family size, an expected frequency of first borns was determined (based on the Misovich model--group size: mean family size).

A Chi-square level of significance test was performed on each of the three groups of data as follows:

$x^{2}=\sum_{i=1}^{2} \frac{\text { (observed freq. of the } i \frac{\text { th }}{\text { bxpected freq. of } i \frac{\text { th }}{} \text { born }}}{\left.\text { Expected freq. of } i \frac{\text { th }}{} \text { born }\right)^{2}}$

where $i=1$ implies first born, $i=2$ implies alj later borns. For these analyses, the number of degrees of freedom $=1$ ( 2 class interval less one constraint). Using the table of percentiles of the chisquare Distribution with $d f=1$, the values of $x^{2}$ were used to interpolate the appropriate levels of significance.

Other pertinent data such as member age, rembership time, and specific birth order were compiled. 
IV

RESULTS

Subjects

Information was obtained from 188 subjects from the three organizations: Lean Line; Alcoholics Anonymous and 5-Day-Flan-ToPuit-Smoking.

Lean Line subjects ranged in age from firteen years to sirty-five: years old. There were 100 subjects in the sample. One hundred questionnaires were distributed and returned. The mean age of she group was 41.2 years, with a standard deviation of 13.63 years. The nembership-age distribution shows a wide range of ages. Se table 1.

Tabie 1

LEAN LIET MEHEERS-AGE DISTIIIBUTION

\begin{tabular}{|l|c|c|c|c|c|c|}
\hline Age in Yrs./ & $10-20$ & $21-30$ & $31-40$ & $41-50$ & $51-60$ & $61-70$ \\
\hline $\begin{array}{l}\text { No. of } \\
\text { Merbers }\end{array}$ & 9 & 16 & 20 & 28 & 19 & 7 \\
\hline
\end{tabular}

Ninety-six percent of the sample was female (96); four percent was rale $(4)$.

Alcoholics Anonymous subjectis ranged in age from seventeen yaars to seventy-two years old. There were fifty-two subjects in the sample.

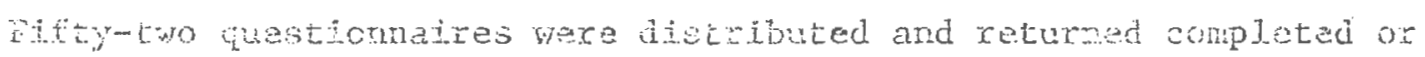


partially completed. The mean age of the group was 42.3 years old with

a standard deviation of 14.54 years. The members-age distribution shows a range of ages. See Table 2 .

Table 2

ALCOHOLICS ANONYMOUS MERBBERS-AGE DISTRIBUT'ION

\begin{tabular}{|l|c|c|c|c|c|c|}
\hline Age in Yrs./ & $15-25$ & $26-35$ & $36-45$ & $46-55$ & $56-65$ & $66-75$ \\
\hline $\begin{array}{l}\text { No. of } \\
\text { Members/ }\end{array}$ & 8 & 8 & 16 & 9 & 9 & 2 \\
\hline
\end{tabular}

5-Day-Plan-To-Quit-Smoking subjects ranged in age from 18 years to 61 years. There vere 36 subjects in the sample. There were thirtyseven questionnaires distributed and returned completed or pariially completed. One was discarded as no birth order infornation was obtained. The members-age distribution shows a range of ages. See Table 3.

$\underline{\text { Table } 3}$

5-DAY-PLAN-TO-QUTT-SMOKING

MEMBERS-AGE DISTRIBUTION

\begin{tabular}{|l|c|c|c|c|c|}
\hline Age in Yrs./ & $15-25$ & $26-35$ & $36-45$ & $45-55$ & $56-65$ \\
\hline $\begin{array}{l}\text { No. of } \\
\text { Nembers! }\end{array}$ & 5 & 8 & 7 & 15 & 1. \\
\hline
\end{tabular}

Seventy-tio percent of the sample was female (26); twenty-aight percent was male (10). 
Membership-Time Information.

Information on subjects' length of membership time was obtained from Lean Line and Alcoholics Anonytious. No information was obtained from 5-Day-Plan-To-Quit-Smoking members as the group only lasted five days.

Lean Line membership time ranged from one week to thirty-two weeks. This information is based on question one of the questionnaire. "How long have you been a member of Lean Line? (If you re-ragistered, approximate the first time)." The majority of members were enrolled three months or less. See Table 4.

\section{Table 4}

LEAN LINE MEMBER-TIME DISTRIBÜTION

\begin{tabular}{|c|c|c|c|c|c|c|c|c|}
\hline $\begin{array}{c}\text { Time in } \\
\text { Weeks./ }\end{array}$ & $1-4$ & $5-8$ & $9-12$ & $13-15$ & $17-20$ & $21-24$ & $25-28$ & $29-32$ \\
\hline $\begin{array}{l}\text { No. of } \\
\text { Members/ }\end{array}$ & 32 & 28 & 14 & 7 & 7 & 3 & 5 & 2 \\
\hline
\end{tabular}

The mean membership time was 9.2 weeks with a staridard deviation of 7.89 weeks.

Alcoholics inonymous membership time ranged from one day io thirty-three years. This information is also based on question one of the A.A. questionnaire, "How long have you been a member of A.A.? (If rejoining, approximate the first time)." "Tho membership-tine 
distribution chart shows the varied membership time. See. Table 5.

\section{- Table 5}

\section{ALCOHOLICS ANONYMOUS MERBER-TIME DISTRIBUTION}

\begin{tabular}{|l|c|c|c|c|c|c|}
\hline $\begin{array}{l}\text { Time in } \\
\text { Years }\end{array}$ & $0-1$ & $1.08-2$ & $2.08-5$ & $5.08-10$ & $10.08-20$ & $21+$ \\
\hline $\begin{array}{l}\text { No. of } \\
\text { Members }\end{array}$ & 18 & 11 & 15 & 4 & 1 & 2 \\
\hline
\end{tabular}

The mean membership time was 3.5 years with a standard deviation of 6.23 years.

\section{Examination of the Hypotheses}

The first hypothesis states that, "There will be a significant difference between the expected number of first borns in a Lean Line group and the observed number of first borns in this group." To verify if the hypothesis is valid, the mean family size had to be computed. Family sizes range from one member in the family to sixteen members. The mean family size for the group of 100 was 4.71 members in a fanily with a standard deviation of 2.91 members.

The expected number of first borns was obtained by $\frac{\text { group size }}{\text { mean fanily size }}=\frac{100}{4.71}=21.23$ expected first borns. Information from questionnaires yielded 30 observed first borns. 
This information was put into a Chi-square level of significance test (described in Chapter 3 , page 22 ). The results $\left(x^{2}=3.62\right)$ indicated a significant difference at the .94 level of confidence. This lends support to the first hypothesis.

The second hypothesis states that, "There will be a significant difference between the expected number of first borns in an Alcoholics Anonymous group and the observed number in this group." As in the firsi hypothesis, the mean family size had to be computed. Family sizes range from one member in the family to ten members. The mean family size for the group of fifty-two was 3.65 members in a family with a standard deviation of 2.15 members.

The expected number of first borns was obtained in the same manner as in the first hypothesis and yielded 14.25 expected first borns. Infornation from questionnaires indicated twenty-five first borns.

This information was recorded into the same Chi-square level of significance test. The results $\left(x^{2}=8.11\right)$ indicated a significant difference at greater than .995 level of confidence. This lends support to the second hypothesis.

The third hypothesis states that, "There will. be a siguificant difference between the expected nuber of first borns in a 5m-Day-Plar-ToQuit---Sruking group and the observed nunber ir the group." The mean Emily size was again computed. Family sizas range from one member in the family to eleven nembers. The moan fanity size for tha gioup of thixty-six was 3.92 members in the fanily with a standard deviation of 2.51 menbers. 
The expected number of first borns was obtained in the same manner as in the first two hypotheses and yielded 9.18 expected first borns. Information from questionnaires indicated 8 first borns.

The information was not recorded into any significance tests as the observed frequency of first borns was lower than the expected number of first borns. These figures do not verify the third hypothesis.

\section{Other Variables}

Examination of the specific birth order of members yielded results that were expected. The table below shows the birth order distribution of the Lean Line group. See Table 6.

Table 6

LEAN LINE BIRTH ORDER DISTRIBUTION

\begin{tabular}{|l|c|c|c|c|c|c|}
\hline $\begin{array}{l}\text { Ordinal } \\
\text { Position }\end{array}$ & 1 & 2 & 3 & 4 & $5-10$ & $10+$ \\
\hline $\begin{array}{l}\text { No. of } \\
\text { Members }\end{array}$ & 30 & 21 & 20 & 8 & 17 & 2 \\
\hline
\end{tabular}

Distribution of birth order among the Alcoholics Anonymous group also shows the expected values for crdinal positions other than first born. See Table 7 .

Table 7

ALCOHOTICS ANONYMOUS BIRTH ORDER DISTRIBUTTION

\begin{tabular}{|l|c|c|c|c|c|c|}
\hline $\begin{array}{l}\text { Ordinal } \\
\text { Position }\end{array}$ & 1 & 2 & 3 & 4 & $5-10$ & $10+$ \\
\hline $\begin{array}{l}\text { No. of } \\
\text { Members }\end{array}$ & 25 & 15 & 6 & 3 & 3 & 0 \\
\hline
\end{tabular}


In the 5-Pay-Plan-To-Quit--3roking group, first born members yielded the expected number. However, the observed frequency of second borns was higher than expected. See Table 8 .

Table 8

5-DAY-PLAN-TO-QUIT-SMOKING BIRTH ORDER DISTRIBUTION

\begin{tabular}{|l|l|l|l|l|l|}
\hline $\begin{array}{l}\text { Ordinal } \\
\text { Position }\end{array}$ & 1 & 2 & 3 & 4 & $5-10$ \\
\hline $\begin{array}{l}\text { No. of } \\
\text { Members }\end{array}$ & 8 & 15 & 6 & 1 & 5 \\
\hline
\end{tabular}

One of the other questions on the questionnaire also provided some significant results. This question, "Have you ever joined other organizations to stop smoking? lose weight? stop drinking?" was particularly significant for the Lean Line group.

Seventy-three percent of the group (73) have joined other organizations to lose weight. One percent (1) have joined other organizations to stop smoking. Zero have joined other organizations to stop drinking.

In the Alcoholics Anonymous group, seven percent (4) have joined other organizations to 1ose weight, zero have joined other organizations to stop smoking, and ten percent (5) have joined other orgarizations to stop drinking.

In the 5-Day-Plan-To-Quit-Sroking group, fourteen percent (5) have joined other onganizations to lose weight, twenty-five percent

(9) have jojned ather organizaticns to stop smoking and seventeen percent (6) have joingd other organizations to stop drinking. 
DISCUSSION AND IMPLICATIONS FOR FUTURE RESEARCH

A discussion of the findings often clarifies certain aspects that may have been ignored in the mechanical listing of the findings. Examination of the sex of the subjects shows that Lean Line members were predominantly female as were 5-Day-P1an-To-Quit-Smoking members. (The Alcoholics Anonymous questionnaire neglected to include a question to obtain this information). Therefore, it could be possible that more females affiliate in social-help organizations. It could also be possible that more females have the problems that these organizations seek to help (i. e., weight reduction, alcoholism, and smoking withdrawal).

The mean age in all three groups was close. Lean Line mean

age was 41.2 years; Alcoholics Anonymous mean age was 42.3 years; $5-D a y-$ Plan-To-Quit-Smoking mean age was 39.8 years. This may irdicate that a particular age group has stronger needs for affiliation. In the Lean Line group, the distribution showed the greatest concentration between ages 41-50 years. In the Alcoholics Aronymous group, the greatest age concentration was 36-45 years. In ths 5-Day-Pian-To-Quit-Smoking group, the concentration was on the 46-55 distribution. As this is a randor sanple, it right be speculated that the highest concentration of members in sorial-telp groups will be hetween thirty-six and fifty-fjve years. 
The length of membership enrollment in the three gruups varied. The highest concentration of Lean Liners (60\%) were members of Lean Line for eight weeks or less. In the Alcoholics Ancnymous group, there was no particular heavy distribution during a particular length of time other than 80 percent of the members were invoived in Alcoholics Anonymous for five years or less. The smoker's group lasted five days -therefore no assumptions about the length of membership can be made. Implications for future research may be the tabulation of daily attrition rates in a 5-Day-Plan-To-Quit-Sroking group. As was warned by Misovich in his study ${ }^{1}$, any findings must be approached with caution as most members have been enrolled for a short time period.

The first two hypotheses,

"There will be a significant difference between the expected number of first: borns in a Jean tine group and the observed number of first boris in this group."

"There will be a significant difference between the expected number of first borrs in an Alcoholics Anonymous groilp and the observed number of first borns in this group."

were proven.

The first hypothesis was prover at the .94 level of confidence; the second hypothesis was yruven at sine .995 level of confilence.

\footnotetext{
Misorich, op. cit.
} 
However, hypothesis three, "There will be a significant difference between the expected number for first borns in a 5-DayPlan-To-Quit-Smoking group and the expected nunber of first borns in that group," was not proven. The levels obtained of first borns were as expected in any random population sample. Several speculations can be made in regard to the findings. The size of the sample, thirty-six subjects, is small. A larger sample might be needed to obtain an accurate birth order distribution. The infrequency of clinics may have been another factor. In the New London, Connecticut area, these smokers" clinics are held only once or twice a year. Advertisements for clinics are small and not attxactive to the public. Another explanation for the finding of expected first torns may be related to the length of time of the smokers' clinics. 5-DayPlan-To-Quit-Snoking, as the name describes, is five days' duration. First borns might not be attracted to such a group because its short duration may not fulfill their affiliative needs. It is presumed that more first borns do not join social-help organizations primarily for the social aspects, but instead for the beneficial aspects. This is an important consideration.

It is this writer's contention that the findings related to smokers be approached with caution and that replication of this aspect of the study is needed. 
Information collected about membership in other or prior socialhelp organizations shows nothing significant or noteworthy except in the case of Lean Liners who have been members of other organizations to lose weight. As was noted in the results, seventy-three percent of the hurdred Lean Iiners had joined other organizations that help members lose weight. This appears to be a very high percentage. It may indicate that prior organizations that help members to lose weight are ineffective.

As was mentioned earlier, the sex of the subjects was not obtained in the Alcoholics Anonymous group. This is a weakness of the study. There are other weaknesses that detract from the validity of the study. In so much as information in the Alcoholics Anonymous group, the study couid not be limited to males or females.

A small geographical area was used to obtain the findings; thus, limiting the scope of the study. The Lean Line questionnaire was biased. This questionnaire refers to the witer as a "fellow Lear. Liner." The other two questionnaires refer to the writer as a "graduate student at U.R.I." Thus, the subjects may be more sympathetic and biased toward the writer and may conplete their questionnaire with a different attitude. When introduced at Lean Line meetings, the writer again was referred to as a fellow Lean Liner. While it is doubtful that this affacts the results of the questionraire, as the information is purely factual, not opinionated, this oversight must be noted. 
Equal sized samples were not obtained from the three organizations. (Lean Line 100, Alcoholics Anonymous 52, 5-DayPlan-To-quit-Smoking, 36). It may be unfair to compare the three groups. However, the calculations used to obtain the statistics were identical for ali groups.

One specific question arose in obtaining the information on the questionnaire. This persistent question was, Do half--siblings and step-siblings count in birth order ranking? The general rule wâs followed: If the subjects grew up with one of these siblings in the same home, he or she should be accounted for in the birth order listing.

No natter how thorough any researcher is, certain weakresses are overlooked in a study. While these weaknesses do detract sonewhat, the information obtained in then is often quite valuable. The fisld of birth order research still remains one of varied findings. This siuby supports Misovich's study as well as other preceding birth order-atfiliation studies. While all studies should be sproached with caution, this study clearly indicates a definite relationsiap between bieth order and affiziation, as defined by mertbership in social--help organizations.

Jt serms imperative that observation and stuily be ione to furtior understani the effect family interaction has on adult

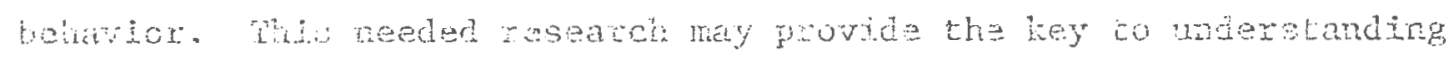
biztin order. 
APPENDIX A

QUESTIONNAIRES AND DIAGRAMS 


\section{NWW LONDON-GROTOA EAST LYME-NORWICH $\because \quad$

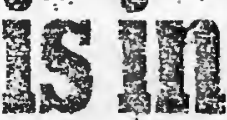
TUESDAY: 9:75 A.M. \& 7:15 P.M. YHCF, RYESAD 5T., NEW 1OPDON

TU $50 A Y: 7: 15$ P.M.HOWARD JOHNSON'S, EAST LYME

TUESOAY: T:I P.M. KAIGHTS OF COLUREUS, HATCH ST., MYSTIC WEDNESOAY:T:75 P.M. GROTON ELKS WEDA WESTESGOK AMULANCE SEFVICE WOUTE 1, WESTBROOK

THUA3RAY: G: 15 A.M., IP.M. \& 7:15 P.M. SHERAEOH MOTOR INA, NORWICH

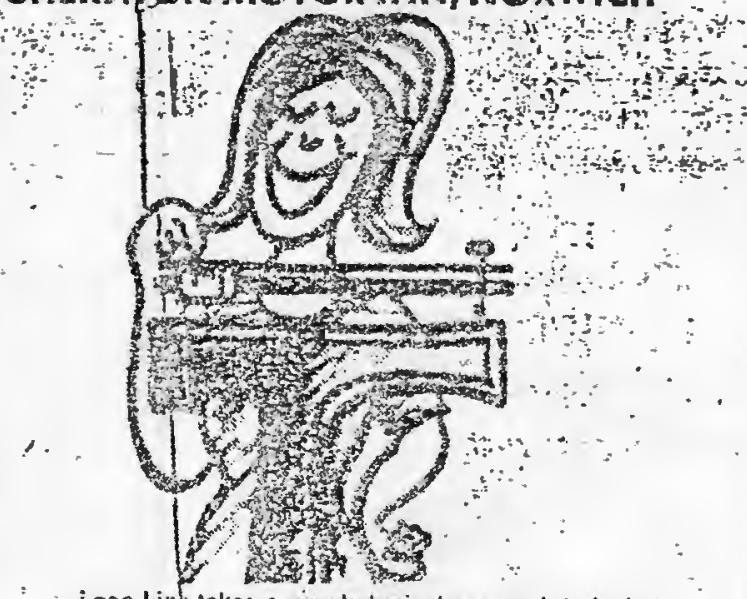

Laan Lin takes a paychological approach to losing weight with at exchisivo univorsity lasted "Eshrrrior Atoxifictivin ivimicen."

Backed th by an 8asy-lo-livo-sith diet that even !ats you oal spagtathi, bagels, lox and panut, buter.

$$
\text { Goll: } 443-4920
$$

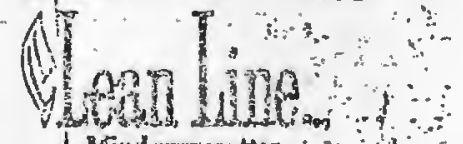

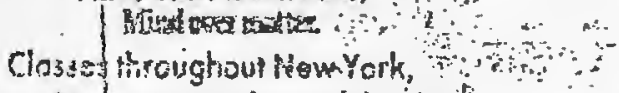

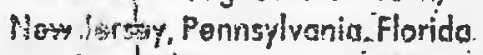

$\therefore$ tomi Connarticut:
(1)

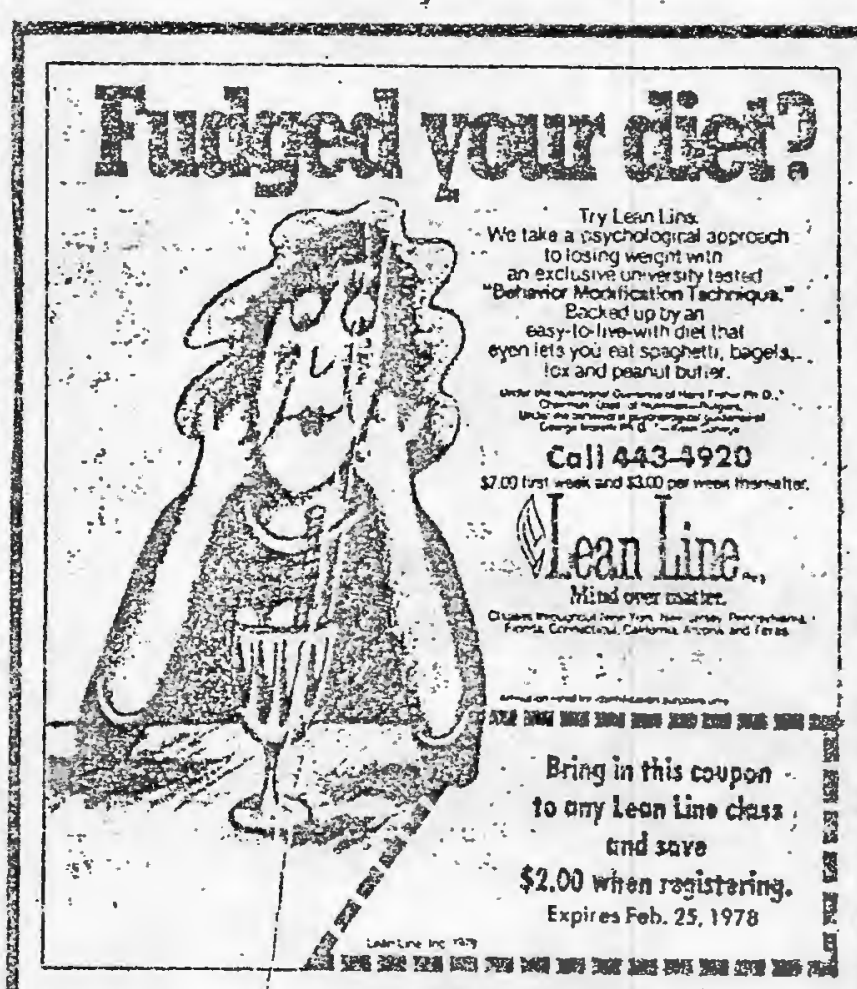

TUES YHCA, RROAD ST. MEN LONDOA TUE.SBAY:7:15 P.M., HOWA A IOHPSON'S, EASTLYME

TUESDAY: 7:15 P.M. KN:SHTSOF COLUMELS, HATCH ST, AMYSTI

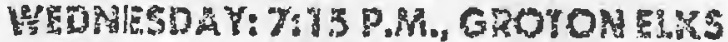
WEDHESUAY: Y5A.MA Z713D.M. WESTBPOOK AMBUL AUT SERVIR ROUTE T, YSFTERONH

THURSTOAY: 9:13 A.M., 3 F.M. SHIERATH MOTORIMN, NOKNICH FHUDSOAY S7\% A.M. GROTOH DKS 
This is a survey taken by one of your Feilow laan Liners. This information Will be used as research data towards her Mastex's Thesis. Please fill out this questionnaire. Do not sign jour rane.

1. How long have you been a menber of Lean Line? (If you re-registered, approximate the 1st time.) weeks

2. Have you ever joined other organizations to lose weight? Have you ever joined other organizations to stop simoling? Have you ever-joined other organizations to stop drinking?

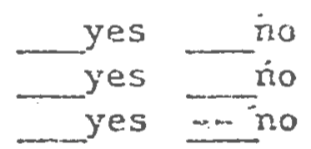

3. How many brothers and sisters do you'have? (Please include daceased brothers and sisters as well.)

Brothers

Sisters

4. What are their agas? (Giva age deceased would be if alive today.) Brothers

Sisters

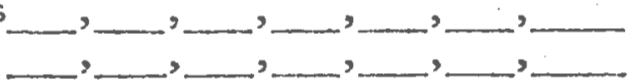

5. That is your ordinal position or bixth ordex in the family? 1st born, 2nd born, $3 \pi$ d bora, 4th born or later

6. What is your. age?

Age

Thank you for your tire. 
This is a survey being taken by a graduze student at J.P.I.. The inforntion :ill be used es research data conards har Master's thesis. please fill out ilis quastionnaire.

Do not siga jour name.

- Hos long have you baen a manber of A.A.? (IE rejoining, approxinate : the first tire.) .

reeks or. monins

- Heve you ever joined other organizations to stop drinking?

Have you evar joined other organizztions to stop sroking?

Have you ever joined othar organizations to lose reight?

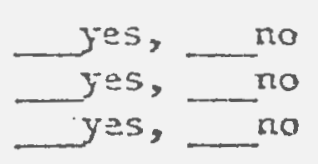

3. Ho: many brothers and sisters do jou have? (Please include deceased brothers and sisters as rell.)

Brothers

Sistiers

f. What are their 2g̈es? (Give ege deceased fould be iE arive todry-)

Brothers

Sisters

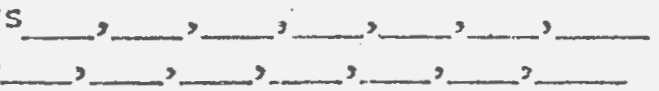

- What is your ordinal position or bizth order ir. the Eanily?

1 st born, 2nd bora, 3rd jorn. 4th boin or later

inat is your age?

Age

Thank you for your tine. 
This is a survey taken by a graduate student at U.R.I.. The information Hill be used as research data towards tar laster's degree. Please fill out this questionnaire.

Do not sign joulr name.

1. Have you ever joined other organizecions to stop swoking? liave you ever joined other organizations to lose weight? Have you ever joined other organization to stop drinking?

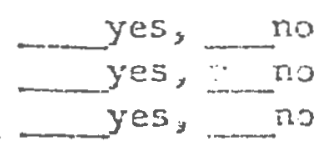

2. How many brothers and sister do you have? (Please include deceased brothezs and sisters as vell.)

Brothers

Sisters

3. Wrat are their ages? (Give age deceased would be if alive today-) Brothers Sisters

4. What is your ordinal position or birth order in the family? Ist born, 2nd boran, 3rd bora, 4th born or later.

5. What is your age? Aga.

6. Wrat is your sex"? Hale, Fenale

Thanic you for your tine. 
APPENDIX B

\section{GRAPHS}


LEAN LINE MEMBERSHIP-AGE DISTRIBUTION

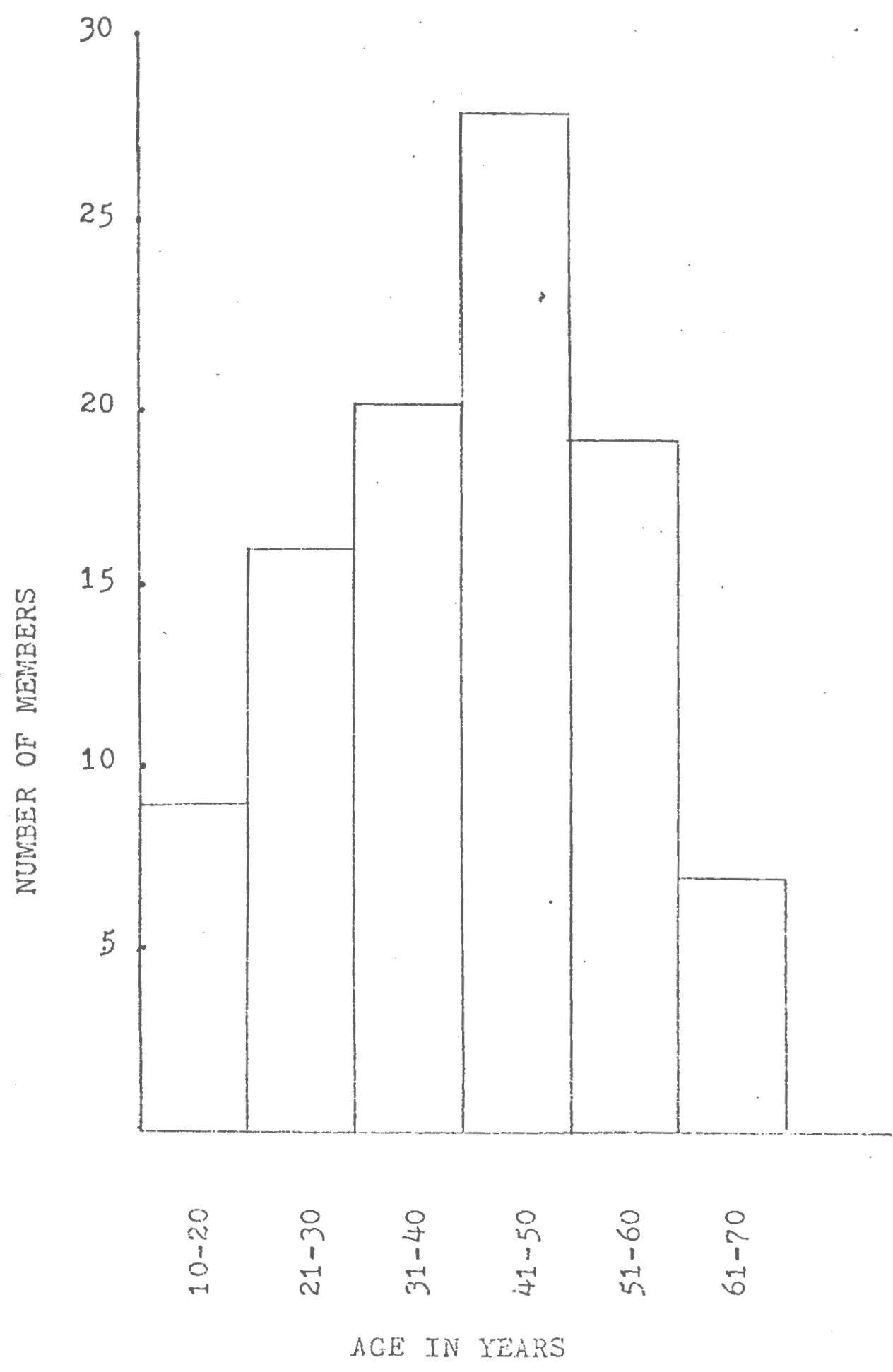


FIGURE 2

43

ALCOHILICS ANONYMOUS MEMBERSHIP-AGE DISTRIEUTION

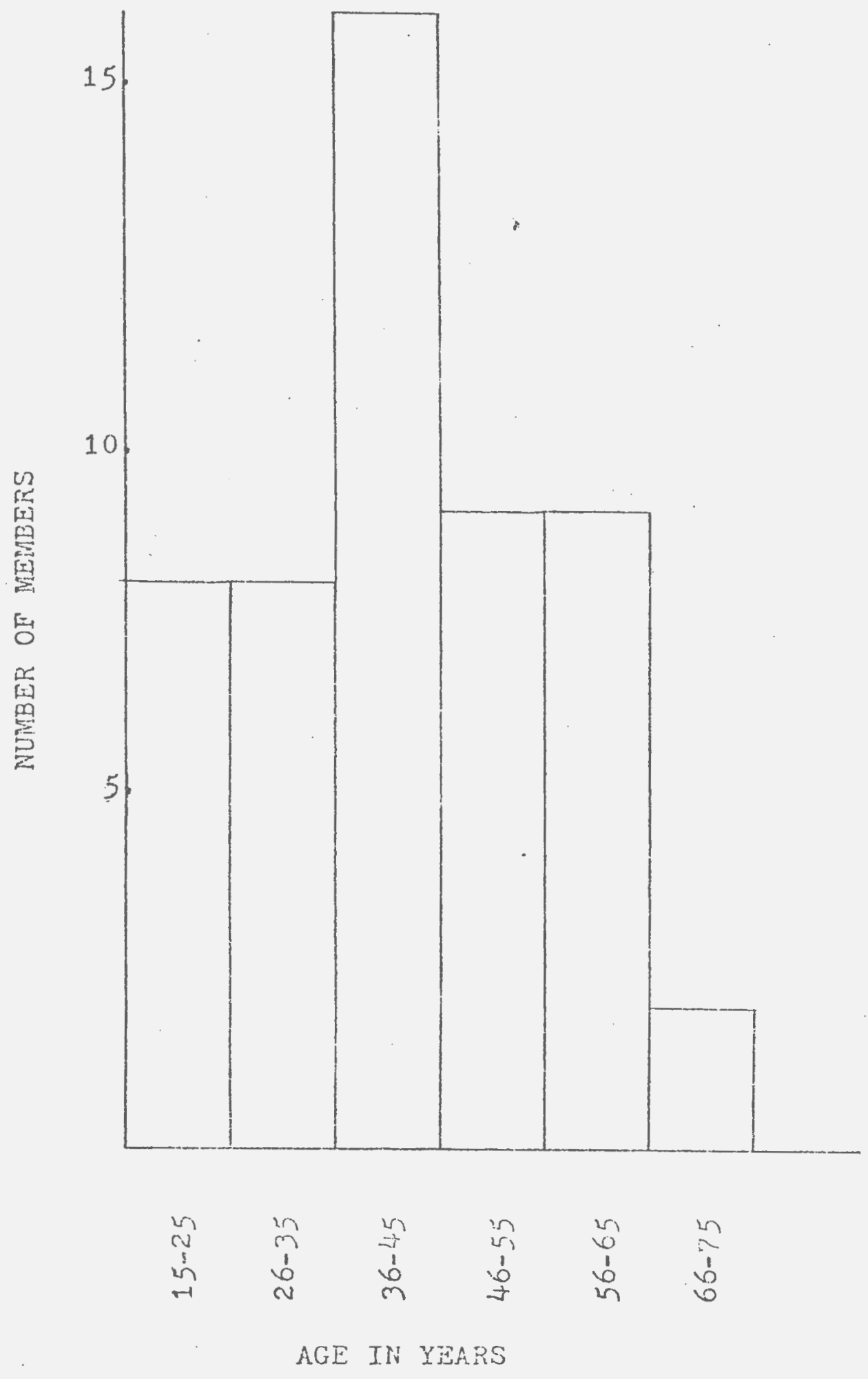


FIGURE 3

5-DAY-PLAN-TO-QUIT-SMOKING MEMBBERSHIP-AGE DISTRIBUTION
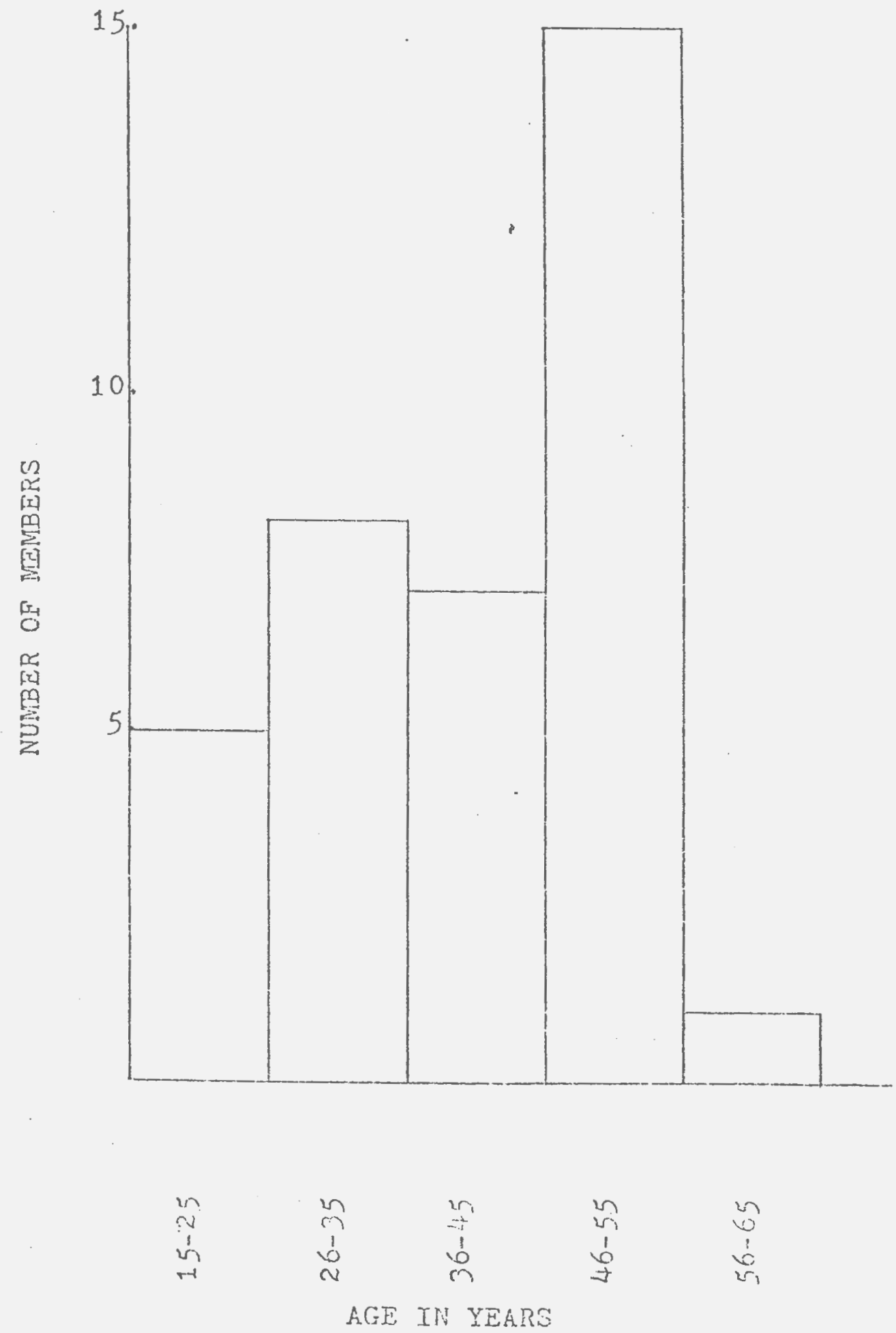
FIGURE 4

NUMBER OF MENBERS VS. MEMBERSHIP-TIME FOR LEAN LINE

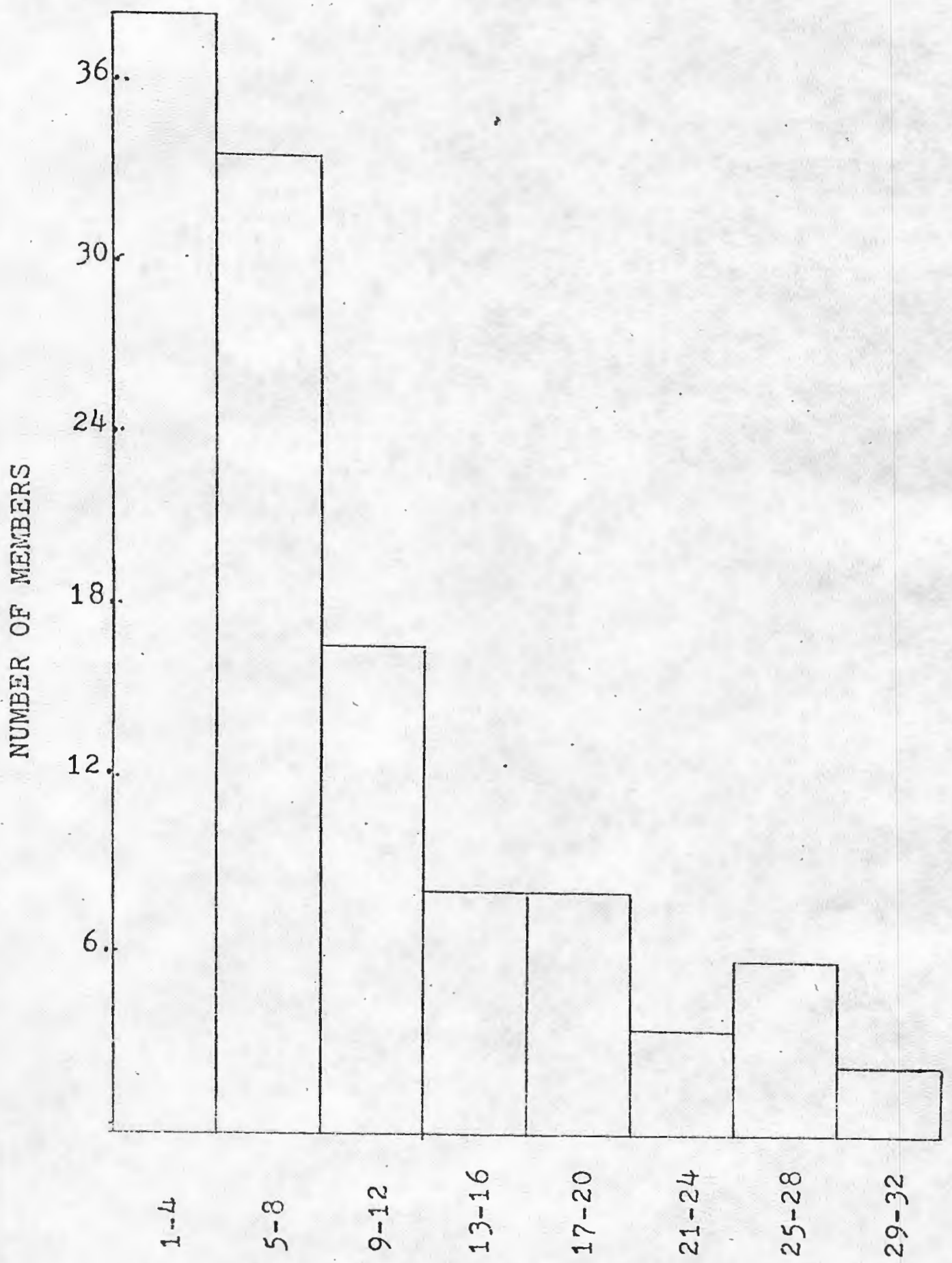

TIME IN WEEKS 


\section{FIGURE 5}

NUMBER OF MEMBERS VS. MEMBERSHIP-TIME FOR ALCOHOLICS ANONYMOUS

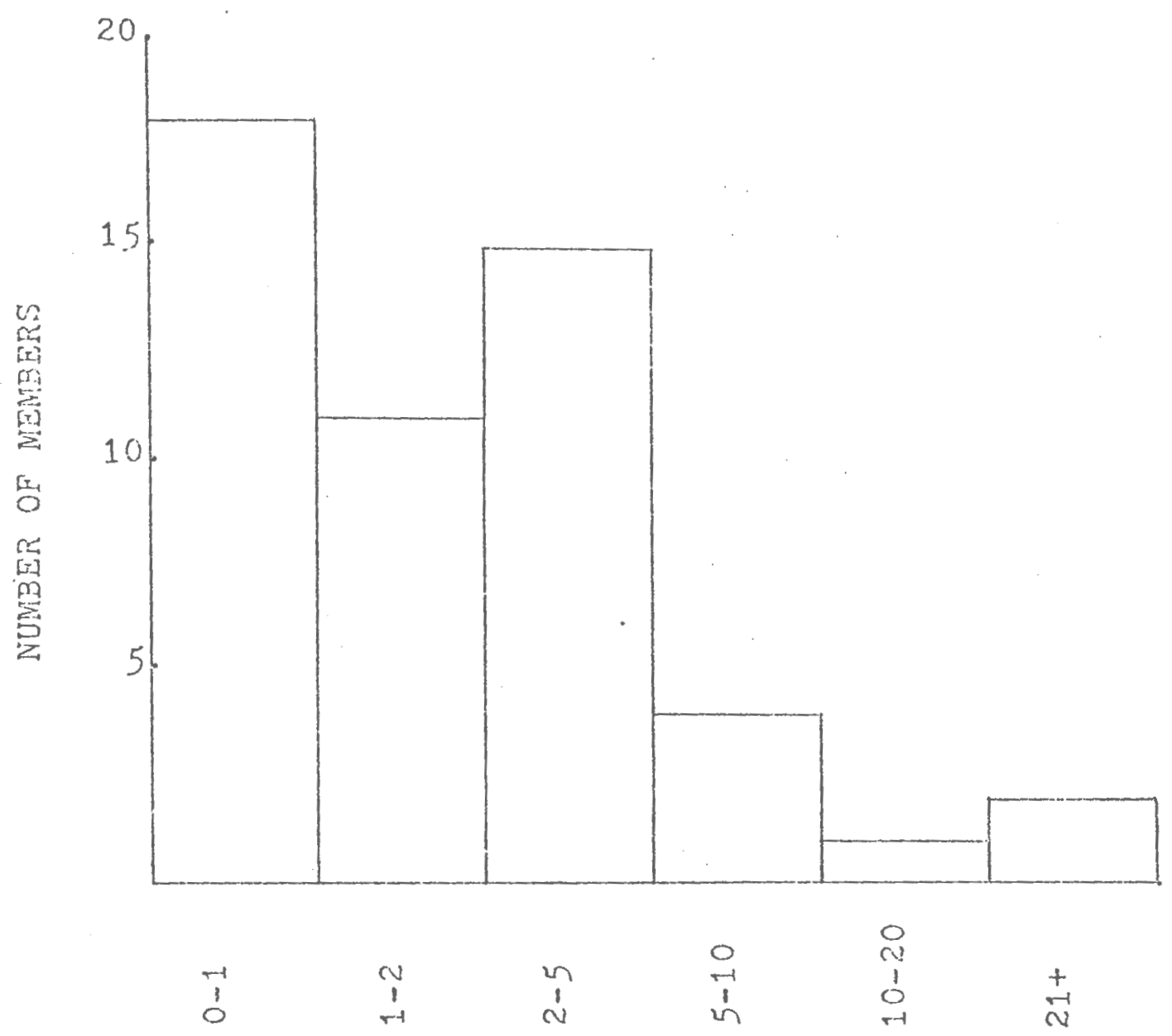

PTME IN YEARS 
NUMBER OF MEMBERS VS. ORDIMAL POSITION FOR LEAN LINE

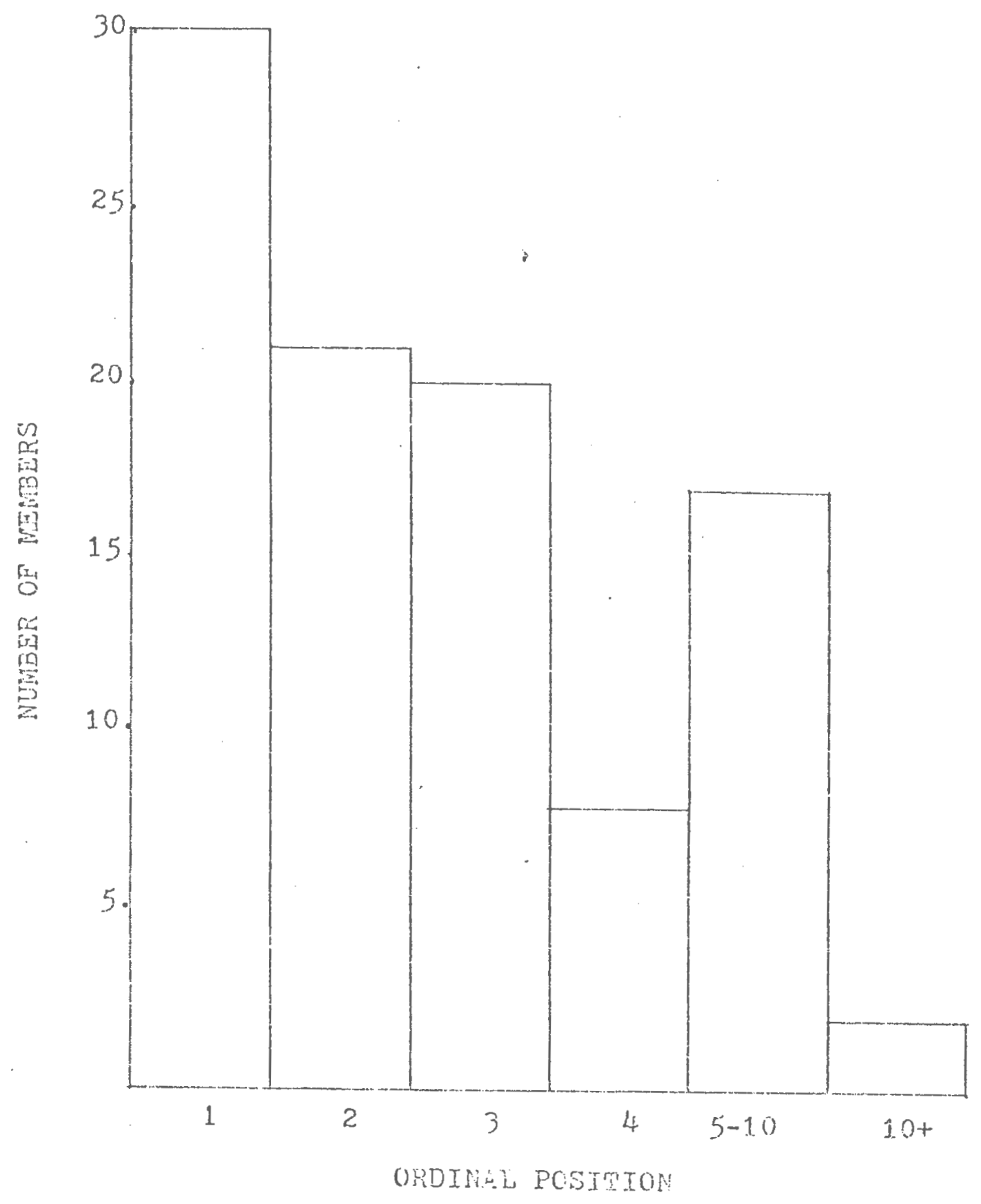


FICIURE ?

UMBER OF MEMBERS VS. ORDINAL POSITION FOR ALCOHOLICS ANONYMOUS

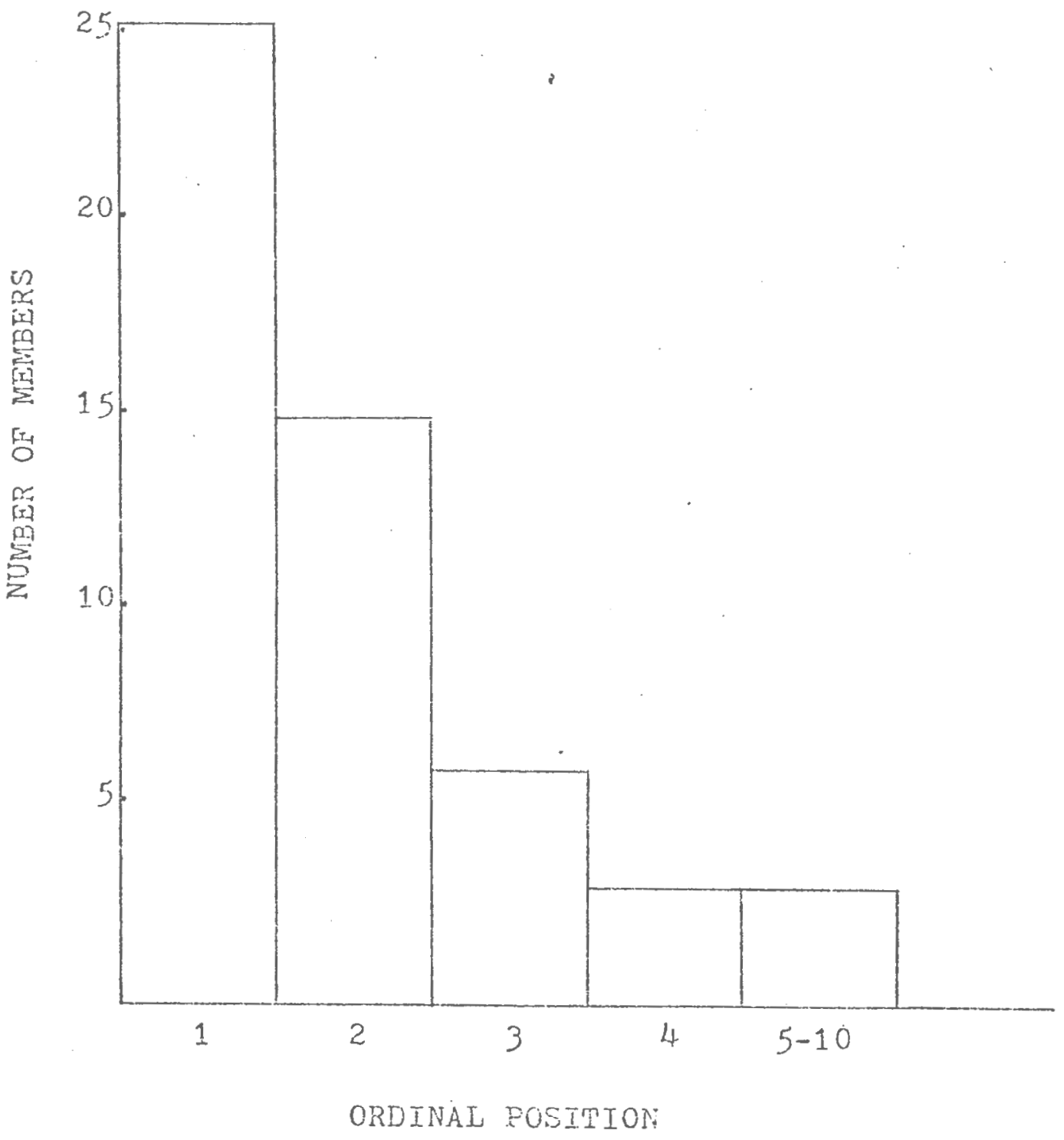


FIGURE 8

NUMBER OF MEHBERS VS. ORDINAL POSITION

FOR FIVE-DAY-PLAN-TO-QUIT-SHOKING

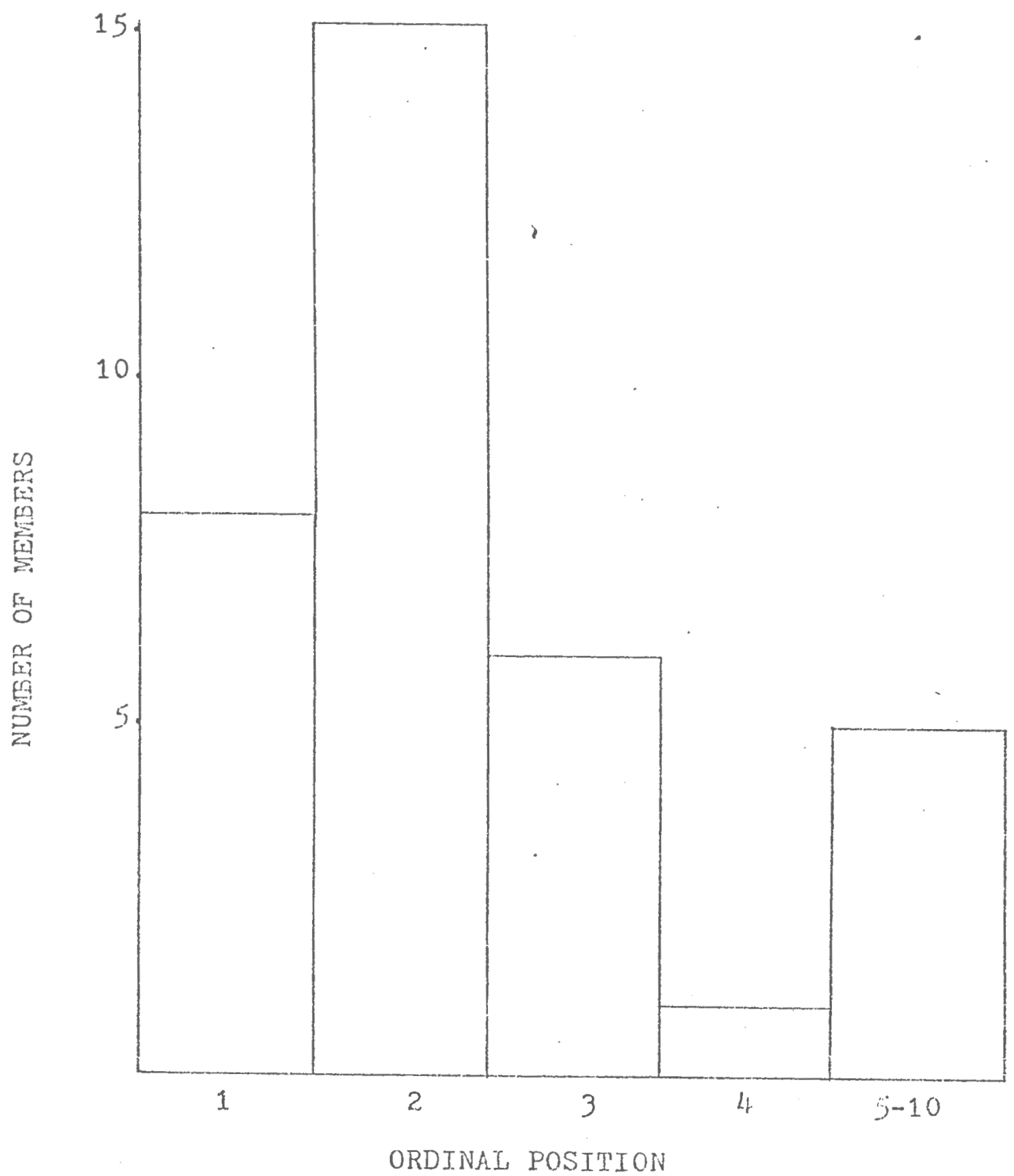


1. Baker, F. and O'Brien, G., "Birth order and fraternity affiliation," Journal of Social Psychology, 1969, 78, 41-43.

2. Blane, H. T., and Barry, H., "Birth order and alcoholism," Quarterly Journal of Studies on Alcohol, 1973, 34 (3) 837-852.

3. Connors, Keith, "Birth order and needs for affiliation," Journal of Personality, 1963, 31 (3) 837-847.

4. Cumps, Carole, "An investigation of ordinal position and sorority affiliation at the University of Rhode Island, "Unpublished study, 1971.

5. Delint, J. E. E., "Alcoholism, birth order, and socializing agents," Journal of Personality, 1963, 31, 408-416.

6. Deraber, W. N., "Birth order and need affiliation," Journa? of Abnormal and Social Psychology, 1964, 68, 553-557.

7. Forbes, George, B., "Smoking tehavior and birth order," Psychological. Reports, 1970, 26 (3) 277-279.

8. Forbes, George, B., "Fraternity or sorority inembership and birth order: Sex differences and problems of reliability," Journal of Social Psychology, 1970, 82 (3) 277-278.

9. George, E. I., and Devadas, R., "Manifest anxiety as a function of birth order," Journal of Indian Academy of Applied Psychology, $1971,9,39-40$.

1.0. Hamilton, M. L., "Affiliative behavior as a furction of approsch and avoidance affiliacion, motives, opinion evaluation and birth order," Journal of Social Psychology, 1967, 72, 61-70.

11. Kosugi, Y., and Tanaka, M., "Parental depwivition, birth orrier, and alcoholism," Japanese Journal of Studias on Alcohol, 10 (j): $70-77,1975$.

12. Marotta, Antonia and Wurtze1, Lorraine. Diet Cybernecics for Lean I,ines, Pyramid Books, New York, New York, 1974. 
13. Masling, Joseph, "Birth order and need for affiliation," Psychological Raports, 1965, 16 (2) 631-632.

14. Misovich, Stephen, "Birth order, affiliation, and membership in Weight Watchers," Psychological Reports, 1973, 32, 94.

15. Murdoch, P., and Smith, G., "Birth order and affiliation," British Journal of Social and Clinical Psychology, 1969, 8 (3) $235-245$.

16. Sarnoff, I., and Zimbardo, P.," Anxiety, fear and social affiliation," Journal of Abnormal and Social Psychology, 1961, 62, $355-359$.

17. Schacter, Stanley, The Psychology of Affiliation, Stanford University Press, Stanford, Cal., 1959.

18. Simon, W. E., "Ordinal position of birth in the family constellation and adult smoking behavior," Jcurnal of Social Psychology, 1973, 90

(1) 157-158.

19. Sinart, Reginald, "Social group membership, leadership, ald order," The Journal of Social Psychology, 1965, 67, 221-225.

20. Smart, Reginald, "Alcoholism, birth order and family size," Journal of Abnormal. and Social Psychology, 1963, 66, 17-23.

21. Strumpfer, D. J. W., "Fear and affiliation during disaster," Journal of Socjal Psychology, 1968, 8, 354-359.

22. Weller, Leonard, "The relationship of birth order to anxiety: A replication of the Schacter findings," Sociometry, 1962, 62, 4.15-4.7.

23. Zucker, R.; Manosevitz, M; and Lanyon, R., "Birth oräer, anxiety, and affiliation during a crisis," Journal of Personality and Social Psychology, 1968, 8, 354-359.

24. Zimbardo, P. and Formica, R., "Tnotional comparison and se1Festem as determinants of affiliation," Iournal of Personality, $1963,141-162$. 